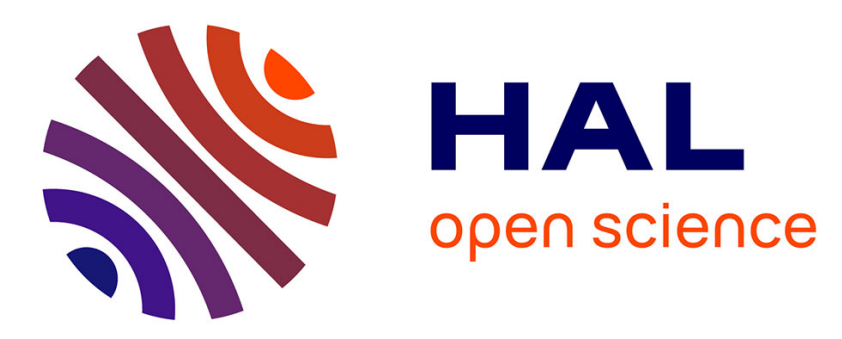

\title{
Menu Costs, Posted Prices, and Multiproduct Retailers
}

\author{
Shantanu Dutta, Mark Bergen, Daniel Levy, Robert Venable
}

\section{To cite this version:}

Shantanu Dutta, Mark Bergen, Daniel Levy, Robert Venable. Menu Costs, Posted Prices, and Multiproduct Retailers. Journal of Money, Credit and Banking, 1999, 31 (4), pp.683-703. $10.2307 / 2601217$. hal-02385591

\section{HAL Id: hal-02385591 \\ https://hal.science/hal-02385591}

Submitted on 28 Nov 2019

HAL is a multi-disciplinary open access archive for the deposit and dissemination of scientific research documents, whether they are published or not. The documents may come from teaching and research institutions in France or abroad, or from public or private research centers.
L'archive ouverte pluridisciplinaire $\mathbf{H A L}$, est destinée au dépôt et à la diffusion de documents scientifiques de niveau recherche, publiés ou non, émanant des établissements d'enseignement et de recherche français ou étrangers, des laboratoires publics ou privés. 


\title{
Menu Costs, Posted Prices, and Multiproduct Retailers*
}

\author{
Shantanu Dutta \\ Department of Marketing \\ School of Business Administration \\ University of Southern California \\ Los Angeles, CA 90089-1421 \\ sdutta@sba.usc.edu \\ Mark Bergen \\ Dept. of Logistics and Marketing Mgmt. \\ University of Minnesota \\ Minneapolis, MN 55455 \\ (612) 624-1821 \\ mbergen@csom.umn.edu
Daniel Levy
Department of Economics
Emory University
Atlanta GA 30322-2240
(404) 727-2941
econdl@emory.edu \\ Robert Venable \\ Robert W. Baird \& Co. \\ bvenable@rwbaird.com
}

JEL Codes: E12, E31

Last Revision: October 20, 1998

\footnotetext{
* The authors are indebted to the editor Paul Evans and two anonymous referees for providing useful comments and suggestions. They are thankful also to Peter Aranson, Robert Carpenter, Robert Chirinko, Christopher Curran, Brett Drey, Steve Hoch, Anil Kashyap, Akshay Rao, Paul Rubin, Bob Ruekert, Jeff Sandgren, Som Somanathan, Wendy Williamson, the late Martin J. Bailey, and the Emory University Economics seminar participants for helpful comments and discussions. All authors contributed equally: we rotate the order of coauthorship. The usual disclaimer applies. Address all correspondence to Daniel Levy.
} 


\section{Menu Costs, Posted Prices, and Multiproduct Retailers}

\section{Abstract}

We use a unique store-level data set to directly measure menu costs and to study the price change process at a large U.S. drugstore chain. We compare and contrast the magnitude of these measures with similar measures from 4 large U.S. supermarket chains. We find that (1) the actual magnitude of menu costs as a share of revenues, (2) menu costs per price change, (3) the frequent use of promotional pricing, and (4) the use of weekly pricing rules, are similar across both retail formats. Given that the main common features of these two types of retail formats are that (i) they both use posted prices, and (ii) both are multiproduct retailers selling a large number of products, our findings suggest that the magnitude of the menu cost components we measure, and the price change practices we document, may be generalizable across retail formats with these two features. 
Authors' affiliations and ranks:

SHANTANU DUTTA is associate professor of marketing at the University of Southern California, MARK BERGEN is associate professor of marketing at the University of Minnesota, DANIEL LEVY is associate professor of economics at Emory University, and Robert Venable is the vice president of equity research at Robert W. Baird, and Co. 
In this paper we use a unique store-level data set to analyse the price change process at a large U.S. drugstore chain, in order to directly measure the costs of changing nominal prices (menu costs) the chain faces. Menu costs play an important role in macroeconomics since they can be a source of price rigidity, and thus can provide a micro-based explanation for monetary non-neutrality. Further, recent studies have demonstrated that menu cost models may be useful in providing answers to numerous questions on the behavior of the short-run aggregate supply curve. Consequently, menu costs have received considerable attention in the theoretical literature as many predictions of the traditional Keynesian and more recent new Keynesian models crucially depend on the existence of some form of price rigidity. Moreover, at the micro level menu costs may form a barrier to individual price adjustments which may lead to inefficient allocations. See, for example, Caplin and Leahy (1991), Mankiw and Romer (1991), Sheshinski and Weiss (1993), Andersen (1994), Ball and Mankiw (1994), Wynne (1995), Romer (1996), Danziger (1999), and studies cited therein.

Yet, despite the theoretical importance of menu costs, little is known about their actual magnitude. The lack of empirical evidence on the magnitude of menu costs has been noted by Gordon (1990), Carlton (1989), Blinder (1991), Carlton and Perloff (1994), and Blinder, et al. (1998), among others. For example, Blinder (1991, p. 90), speaking about menu cost theories, states: "In principle, fixed costs of changing prices can be observed and measured. In practice, such costs take disparate forms in different firms, and we have no data on their magnitude. So the [menu cost] theory can be tested at best indirectly, at worst not at all." Indeed, of the empirical evidence that does exist, almost all rely on indirect assessment of the importance of menu costs. These studies include, Sheshinski, Tishler, and Weiss (1981), Rotemberg (1982), Lieberman and Zilberfarb (1985), Carlton (1986), Cecchetti (1986), Danziger (1987), Ball, Mankiw, and Romer (1988), Carlson (1992), Lach and Tsiddon (1992, 1996a, 1996b), Eden (1994, 1995, 1996), Amano and Macklem (1995); Ball and Mankiw (1995); Kashyap (1995), Warner (1995), Warner and Barsky (1995), Balke and Wynne (1996), Buckle and Carlson (1996), Slade (1996, 1998), and Blinder, et al. (1998).

Several authors such as Gordon (1990) and Ball and Mankiw (1994), have expressed the view that menu costs, if interpreted literally, may not be high enough to cause substantial effects. It has been argued, therefore, that these costs should be viewed metaphorically, like a parable, to formalize the fact that prices are not adjusted continuously. For example, according to Ball and Mankiw (1994, p. 143), "Walras observed that prices move to equilibrate supply and demand, and he captured this tendency with the parable of an auctioneer. Similarly, macroeconomists have noted that many prices are sticky in the short run, and they capture this fact with the parable of menu costs. It is no more appropriate to insist on an exact identification of menu costs than it is to demand the social security 
number of the Walrasian auctioneer."

Nevertheless, in Ball and Mankiw’s view “... it is still interesting to go beyond the parable to better understand the foundations of nominal frictions. Future research could examine informationgathering and processing costs in actual firms, for example." Slade (1998, p. 104) also suggests that “... given the large number of theoretical papers that evaluate the implications of [price] adjustment costs, obtaining direct evidence that such costs are present seems crucial." In this paper we follow this line of thought and argue that given the theoretical importance of menu costs, it can indeed be very valuable to identify and, if possible, measure these costs of changing prices in real market settings. This is because such an identification and measurement can be useful for our understanding of the empirical relevance of menu costs. Further, documenting and measuring these costs are a useful step toward our understanding of why these costs might exist. Finally, studying the structure and magnitude of menu costs across variety of markets, industries, and countries, can be valuable for our understanding of the role menu costs play in the variation of price rigidity across these and other dimensions (Caplin, 1993).

In this paper we contribute to this literature by using a unique store-level data set to provide direct measures of menu cost and a detailed analysis of the price change process, at a large U.S. drugstore chain. We have dollar measures of two components of menu costs: (1) the costs of the labor used in changing price tags on the store shelves, and (2) the costs of printing and delivering the shelf price tags. Our data set allows us to measure these costs in great detail, documenting the exact time required for each stage of the price change process and the costs associated with them. We also describe the exact mix of the various price changes the chain makes in a typical week, from basic price changes to specific promotional price changes such as sales, rebates, and clearance. Further, we provide evidence that stores in this chain change prices on a weekly basis, closely resembling time-dependent pricing rules often employed in the new Keynesian cost of adjustment literature.

This paper builds upon the study of Levy, Bergen, Dutta, and Venable (1997) who have documented the price change process and provided direct measurements of menu costs for another type of retail format, large U.S. supermarket chains. Here we extend their work to a different type of retail format, chain drugstores. Given that numerous authors (e.g., Lach and Tsiddon, 1992; and Ball and Mankiw, 1994) have suggested the importance of studying price setting at establishments selling small staple retail items, this extension to drugstores is a natural step forward in the study of menu costs. We compare and contrast the findings we report here for the drugstore chain to their findings for the supermarket chains. For the most part we find that the results Levy, et al. (1997) report in their paper for supermarket chains continue to hold for the chain drugstore. Specifically, we find that menu costs per price change, menu costs as a share of revenues, as well as the level of promotional 
activity, and the time-dependent nature of the price change decisions, are similar for the drugstore and the supermarket chains. Given that the common features of these two types of retail formats are that (i) they both use posted prices, and (ii) both are multi-product retailers selling a large number of products, our findings suggest that the magnitude of menu cost components we measure, and the price change practices we document, may be generalizable across retail formats with these two features, such as department stores, hardware stores, specialty stores, etc., where the steps involved in the price change process are likely to be similar to the steps reported and documented here.

For the components of the price change costs we are able to measure in dollar terms, we find that menu costs for the chain drugstore average $\$ 0.33$ per price change which comprises about 0.59 percent of revenues. This is similar in magnitude to menu cost of $\$ 0.39$ per price change comprising 0.53 percent of revenues Levy, et al. (1997) report for large U.S. supermarket chains (for the same components of menu costs). These menu cost figures are nontrivial and if interpreted in the context of the existing theoretical models of menu costs, they may even be sufficient to form a barrier to price changes. Moreover, given that menu cost figures we report here do not include several components of broadly defined menu costs, our menu cost estimates may be considered a lower bound of the true costs of changing prices. This, combined with the findings of Akerlof and Yellen (1985), Mankiw (1985), Parkin (1986), Blanchard and Kiyotaki (1987), and Caplin and Leahy (1997) among others, that even small menu costs may be sufficient to generate substantial aggregate nominal rigidity, suggests that costs of physically changing prices, at least in the type of establishments we study, may be higher than previously thought (Carlton, 1989; Gordon, 1990; and Ball and Mankiw, 1994).

The quantitative significance of our findings becomes evident if we recall that supermarket and drugstore chains combined constitute about $\$ 450$ billion in annual sales, or about 20 percent of the total retail sales. Since retail sales account for about 9.3 percent of the GDP, the menu cost figures we find may apply to as much as 1.93 percent of the GDP which is substantial. Moreover, since the price change practices we document here are commonly used in other types of multiproduct retail establishments, such as department stores, hardware stores, and specialty stores, the menu cost figures we present here likely apply to much larger proportion of the retail sales.

We also describe the price change activity of the drugstore chain in some detail. We provide evidence that a large percentage of the drugstore price change activity is promotional, as is the case also in retail supermarket stores. ${ }^{1}$ This points to the promotional nature of many price changes in markets where posted prices are the norm and suggests that the benefits to frequently changing prices can be high when firms post prices, which is consistent with arguments made by Hoch et. al (1995), Carlton (1986), and Bergen, Dutta and Shugan (1996). We also provide evidence on the weekly schedule and timing of price changes which suggests that the price change decisions in the chain drugstore have some time-dependent element. This provides empirical support for the assumption of 
time-dependent pricing schemes frequently employed in the cost of adjustment literature.

The rest of the paper is organized as follows. The data set is described in section 1. In section 2, we describe in detail the structure of the menu costs and their absolute magnitude at the chain drugstore. In section 3, we describe relative measures of the menu costs and discuss their quantitative significance. In section 4, we discuss the price change activity of the chain drugstore, and in section 5, we present evidence on the chain's timing of price changes in the context of timedependent pricing rules. In section 6, we conclude with suggestions for future research.

\section{THE DATA}

The data come from a company that sells electronic shelf label systems. ${ }^{2}$ These systems allow retailers to manage the pricing in real time by displaying the shelf prices on a small calculator-like digital displays attached to the shelves. The system consists of a PC based system controller, wireless communication network, and electronic shelf labels and rails. Obtaining information from the in-store item and the data base, the system broadcasts this information to the shelf labels through a controller at each gondola. The system also maintains a continuous surveillance of the electronic shelf labels to ensure that they are present and that they are displaying the correct information. In addition, this label polling process creates data on the physical location of the label within the store. The system is controlled wirelessly from a central computer where price changes are actually done. Because of this setup, the electronic shelf label systems can be used by drugstore chains to greatly reduce the physical costs, lead times, and the frequency of mistake occurrences currently associated with changing paper-tag based shelf prices. In order to sell the product, the electronic shelf label company had to quantify the measurable benefits of its electronic shelf label systems. For this they had to measure the existing costs of changing shelf prices, i.e. menu costs. This company received access from corporate headquarters of the drugstore chain to go to representative stores of the chain and carefully record the exact steps involved in the price change process. A researcher worked with the people involved in the process of changing prices on the store floor where the shelf tags were physically changed, and undertook detailed time and motion measurements to estimate the frequency of various steps undertaken in the price change process, along with the required labor time and cost of each step. The study required hundreds of man hours to complete and was conducted over a four month period, from July to October of $1992 .^{3}$

The study considered the entire price change and its implementation process in the chain. Observations of the process were conducted in four stores of the chain to verify its accuracy. Information received from the chain's pricing systems, in-store observations, and in-store counts and measurements were used to determine the volume of work performed in each step of the tasks, the weekly frequency of each step performed, and the amount of time required to perform one unit of the 
work. After computing the total hours per task, this information was reconciled with the known total hours spent each week. This allowed for task level comparisons for the existing and test process.

Although we believe menu costs reported in this paper are representative of menu costs in the U.S. drugstore industry, we should mention that they may be biased upward because the electronic shelf label company had an incentive to overestimate the magnitude of menu costs in order to sell its computer-controlled price change systems. We, however, think that menu cost measures we report here are not subject to significant biases of this sort for a number of reasons. First, the measurements were made by the electronic shelf label company people working alongside with the chain's employees, together following and documenting their activities, and using the company's wage figures. Second, time and motion measurements of the type used for measuring menu costs we report here are routinely done by drugstore chains themselves in order to assess the efficiency of their price change processes. The managers compared their figures to the electronic shelf label company figures and in most cases found them to be similar. If there was a discrepancy between the two, the electronic shelf label company studies used the more conservative estimate. Further, these figures were presented to upper management of the chain and they were found to be representative of its cost structure. Moreover, the validity of menu cost estimates constructed by the electronic shelf label company was not disputed in these meetings. If there was any disagreement between the electronic shelf label company and the chain, it was about the size of the savings the electronic shelf label system would provide, not about the accuracy of menu cost measurements themselves. Finally, we looked at these reports and searched for figures that could be biased upward. There were a few, such as goodwill cost inventory holding cost estimates, and to be on the conservative side, we did not include them in our measures of menu costs. Thus we only report measurements for which we could see no upward bias. Note, however, that menu cost figures we report here for the drugstore chain are also biased downwards because we were unable to measure in dollar terms several components of menu costs and thus they are not included in our estimates.

The retailer involved in this study is a large U.S. drugstore chain. ${ }^{4}$ At the request of the chain and the electronic shelf label company, we need to keep the chain's name anonymous. Thus, we are not able to report any detailed description of this chain, but it is reasonably representative of large drugstore chains currently selling in the U.S. According to the National Association of Chain Drugstores, as of 1995 there were 28,381 chain drugstores operating in the U.S. with total annual sales of $\$ 65.1$ billion. $^{5}$ This comprises about 80 percent of the total, chain and independent drugstore sales (combined) of $\$ 81.4$ billion, so the chain in our study is a representative of a major class of the retail trade. 6

Table 1 reports some general information about the chain drugstore we study. According to the 
first column of the table, the drugstore chain tends to carry around 15,000 different products on a regular basis. ${ }^{7}$ On an average week the stores of the chain change prices of 1,131 products, which comprise about 7.5 percent of the products they carry, on average. ${ }^{8}$

\section{ABSOLUTE MEASURES OF MENU COSTS}

Our data contains dollar measures of the following two components of menu costs: (1) the costs of the labor used in changing price tags and price signs on the store shelves, and (2) the costs of printing and delivering these shelf price tags and the price signs. The former consists of (i) the cost of labor used in preparation of the price change process, (ii) the cost of labor used to actually change the shelf price tags and the price signs, and (iii) the labor cost of verifying the accuracy of the price changes once these changes have been implemented. Below, we go through each of these cost components in more detail (see Table 2) followed by a comparison of the results we report here for the chain drugstore with the results Levy, et al. (1997) report for large US supermarket chains.

\subsection{Cost of the Labor Used to Change Shelf Prices}

The price change process, as described below, is performed each week. The only difference from week to week is in the products for which the prices are changed. A price change process begins by preparing for it. For this new shelf price tags and price signs are ordered and delivered, which are sorted by departments. The information on specific price changes and the products to which they apply is also received in the form of computer printout. As the price change time approaches the store-level employees in charge of the price change process collect these reports and price tags and signs along with office supplies and go to the designated aisles where the shelf price tag and price sign changes are physically done. To compute the total labor time used in changing prices on a weekly basis, we combine data collected through in-store time and motion observations with the information on the volume of products for which prices are changed. These weekly hours are multiplied by the wage rates (adjusted for fringe benefits) of the employees used in the price change process to give us the total menu costs associated with the labor required to change prices.

Labor cost of price change preparation: The store-level price change preparation on average takes 13 weekly hours, of which 8 hours are spent on Mondays (4 hours are spent on cosmetics products, 2 hours on over-the-counter products, and 2 hours on the rest of the products), and 5 hours-on Fridays on all advertised (i.e., sale) products. The hourly wage of the workers doing this preparation is $\$ 9.40$, which includes $33 \%$ loading for fringe benefits. Thus, the annual labor cost component of menu costs spent on price change preparation equals $13 \times 52 \times 9.40 \times 0.7948=\$ 5,050 .{ }^{9}$ This comprises 32.7 percent of the total labor cost component we measure in this study. 
Labor cost of the actual price changes: The physical shelf price tag and price sign change process is very repetitive and time consuming and involves the following main steps. A worker collects the new price tags and the new price signs along with the computer print out of the list of the products for which prices need to be changed. Then the worker needs to locate the aisle, followed by the product category group, and finally the product itself. Once the product is located, the worker removes the old price tag or the price sign from the shelf and replaces it with a new price tag or a price sign. These steps are repeated until all price changes are done. In total, the chain drugstore on an average week uses 21.8 hours of labor to actually implement these price changes, which in annual terms costs $21.8 \times 52 \times 9.40 \times 0.7948=\$ 8,469$. This is the largest component of the labor cost we measure in this study, comprising 54.8 percent of the total labor component of menu costs. ${ }^{10}$

Labor cost of price change verification: Chain drugstores put considerable effort and resources into building customer confidence that they offer low prices. Frequently, however, discrepancies occur between the price at the shelf and the price at the checkout cash register. This damages the consumers' confidence which imposes costs on the retailer in the form of lost customer goodwill and the resulting damaged reputation for the chain, which can be substantial (Okun, 1981). To minimize these costs, workers equipped with a list of new prices go back to the aisles to verify that the price changes have been done correctly. This task requires an average of 5 hours per week, leading to annual menu cost of $5 \times 52 \times 9.40 \times 0.7948=\$ 1,942$. This is the smallest component of the labor cost we measure in this study, comprising only 12.5 percent of the total labor cost component of menu cost.

Thus, the total annual labor cost of price change preparation, price change implementation, and price change verification comes to $5,050+8,469+1,942=\$ 15,461$ (see Table 2, row 1). The labor costs associated with changing prices are the largest component of menu costs we report in this study, making up about 79 percent of the total menu costs. Note however, that menu cost measures we report do not include several components of menu costs which is likely biasing downwards the estimates of menu costs.

\subsection{Costs of Printing and Delivering New Price Tags}

There are direct costs associated with printing and delivering the price and sign tags. The order for new price tags and price signs must be recorded and processed at the chain, sent to the printer, recorded and processed at the printer, printed, packaged, and then delivered to each store. The total annual stock and printing cost of price tags equals $\$ 4,778$ per store, which is based on 1,423 price tag changes. Therefore, after multiplying this by the factor of 0.7948 , we get a total annual cost of $\$ 3,797$, which is equivalent to 6.46 cents per price tag (for 1,131 weekly price changes). The annual cost of delivering these price tags, after similar adjustment, comes to $\$ 362$ per store, which is 
equivalent to 0.62 cents per price tag. These two figures combined yield $\$ 4,159$ per store as the total annual cost of printing and delivering price tags (see Table 2, row 2). These costs comprise about 21 percent of the total menu costs we report in this study.

\subsection{Total Menu Costs}

The total annual menu cost for this drugstore chain is the sum of the components described in sections 2.1-2.2, which according to the third row of Table 2, yields a total amount of $\$ 19,620$ per store on average.

It should be emphasized that in this paper, as in Levy, et al. (1997), we only report measures of the marginal cost of changing prices. The costs of putting a price tag for the first time, and other costs that would be included in the average cost, are not included in the figures we report. Moreover, the most time consuming steps of the price change process need to be repeated each time a price is changed. These include the steps undertaken during the stages of changing a price tag, changing a

price sign, and verifying that these changes were done correctly. ${ }^{11}$ Also, we could not find many tasks that generated significant returns to scale. Further, the menu cost measures we report do not include the cost of changing prices in cases where items are moved from shelf to shelf, or where shelf space is reallocated by increasing the shelf space for some products at the expense of others. However, they do include the cost of pricing new products when they are first introduced. Although this could bias the menu cost measures upward since it really captures the cost of pricing rather than the cost of changing price, the size of this bias in comparison to the number of products for which prices are changed each week $(1,131)$, is marginal due to the small number of new products (about 10-30) the chain drugstore introduces each week.

\subsection{Comparison with Supermarket Chains}

As Table 2 indicates, in absolute terms the total annual menu costs per store for the chain drugstore comprises only about a quarter of the total annual menu cost of the supermarket chains. The main reason for this difference is the significantly less frequent price change activity at the drugstore chain: we find that the chain drugstore changes prices on an average of 1,131 products each week in contrast to an average of 3,916 products at the supermarket chains. The large difference in the frequency of price change activity between these two retail formats may be due to differences in the target customers of the two retailers. Specifically, studies have shown that supermarket customers may be more price sensitive than drugstore customers (Quelch, 1981; and Bob Ruekert, in private conversations). Further, most people spend more money in supermarkets than in drugstores: a basket of products bought on an average trip to a drugstore is significantly smaller than what most of us buy during our weekly supermarket visit, and according to Nagle and Holden (1995), 
customers tend to be more price sensitive when total expenditures are higher, ceteris paribus. Another reason for this difference may be the different shopping patterns and buying cycles of customers frequenting these two types of retail formats. Customers at drugstores tend to buy much less frequently relative to supermarket customers who usually shop for the basic items at least on a weekly basis. Also, the purchases made at drugstores tend to be more random. ${ }^{12}$ The lower frequency of price changes at chain drugstores is a major reason why chain drugstores have the lower menu cost per product and the lower menu cost to gross margin ratio relative to the supermarket chains.

\section{RELATIVE MEASURES OF MENU COSTS AND THEIR QUANTITATIVE SIGNIFICANCE}

In order to assess their relative magnitude, we express the absolute measures of the annual menu costs relative to the chain drugstore's (i) net margins, (ii) revenues, and (iii) number of price changes (see Table 3, rows 3-5). ${ }^{13}$ Below we discuss these figures and compare them with the figures reported by Levy, et al. (1997) for large US supermarket chains.

\subsection{Relative Measures of Menu Costs}

Net margins of chain drugstores of the size studied here average about 2.75 percent of revenues. Further, the revenue for an average store is about $\$ 3,350,000$ (see notes d-e underneath Table 3 for the source of these figures), and therefore, menu cost to net margin ratio at this chain drugstore averages 21.3 percent, which seems substantial. ${ }^{14}$ As a share of revenues, menu costs comprise 0.59 percent. Finally, we find that menu costs at an average store equal $\$ 0.33$ per price change, which is computed as the ratio of the total annual menu costs $(\$ 19,620$, from Table 2$)$ to the annual frequency of price changes $(1,131 \times 52$, from Table 1$) .{ }^{15}$

\subsection{Comparison with Supermarket Chains}

In order to compare these figures to the estimates reported by Levy, et al. (1997), in the right hand side of Table 3 we report equivalent relative measures of menu costs for four large U.S. supermarket chains they study. Menu cost per price change in these supermarkets average $\$ 0.39$, which indicates that the magnitude of menu costs per price change is similar across these two types of establishments. Further, menu cost to revenue ratio at these supermarkets average 0.53 percent, which again is similar to the magnitude of 0.59 percent we find for the drugstore chain.

Menu cost figures we reported so far only include the labor and price tag costs. In addition to these two components, menu cost measures reported in Levy, et al. (1997) also include the costs of mistakes made in the price change process as well as the costs of in-store supervision of the price change process. It turns out that the relative magnitude of menu cost figures we find for the chain 
drugstore do not change dramatically if we add estimates of these two components. For example, in the bottom three rows of Table 2 we report the estimates of these two components along with total estimated annual menu costs for the supermarket chains as reported in Levy, et al. (1997), along with the corresponding figures for the chain drugstore. In estimating these costs for the chain drugstore, we have used the ratio of the missing components (mistake and in-store supervision costs) to the labor cost, as reported for the supermarket chains, to approximate the corresponding ratios for the drugstore. ${ }^{16}$ In the bottom three rows of Table 4, we report the key relative measures of total menu costs per store: the ratios of menu costs to net margins and menu costs to revenues, and menu costs per price change. As the table indicates, these figures remain stable across the two retail formats. These findings suggest that at least for the menu cost components considered, the menu cost figures reported here and in Levy, et al. (1997), may be generalizable across multiproduct retail formats that rely on posted prices.

\subsection{Quantitative Significance of the Menu Cost Figures}

To appreciate the quantitative significance of our findings, note that supermarket and drugstore chains combined constitute about $\$ 450$ billion in annual sales, or about 20 percent of the total retail sales. ${ }^{17}$ Retail sales account for about 9.3 percent of the GDP. ${ }^{18}$ Therefore, the menu cost figures we find may apply to as much as 1.93 percent of the GDP. Moreover, the menu cost figures we present here likely apply to much larger proportion of the retail sales. This is because the price change practices we document here are commonly used in other types of multiproduct retail establishments, such as department stores, hardware stores, specialty stores, etc.

In order to assess the macroeconomic relevance of the menu cost figures we find, consider the numbers reported in Table 3, which show that the menu cost to revenue ratio for the drugstore chain averages 0.74 percent. Similar figures have been reported for the retail supermarket chains by Levy, et al. (1997) which suggests that these figures and the conclusions that follow from them may be generalizable to broader category of multiproduct retail settings that rely on posted prices. Levy, et al. suggest that menu cost of this magnitude is non-trivial and may be sufficient to form a barrier to price changes, when interpreted in the context of the theoretical menu cost models of Blanchard and Kiyotaki (1987) and Ball and Romer (1990). The existence of numerous unmeasured menu cost components discussed below also raises the strong possibility that the actual menu costs incurred by the drugstore chain may be even higher. However, we do not want to overemphasize the linkage of our empirical findings with these theoretical models. This is because unlike the frequent price changes in the chain drugstore, in the macroeconomic environment of these models prices can go unchanged for appreciable periods of time.

Finally, some components of menu costs we were unable to measure due to data limitations. 
These include the cost of changing prices of the products handled by direct store delivery vendors, the costs implicit in the lost customer goodwill caused by mistakes made in the price change process, costs of informing customers on price changes (advertisement cost), and the costs of making corporate level managerial decisions on price changes. The amount of direct store delivery is much lower in drugstores than in supermarkets (about $2-5$ percent, in contrast to $20-40$ percent in supermarket chains), and the costs induced by the mistakes made in the price change process are also likely to be lower due to the lower volume of prices changed each week.

Costs of managerial decisions on price changes, however, may be important. Several authors have suggested that this may be one of the most important components of menu costs. ${ }^{19}$ Much like supermarket chains, prices at drugstore chains are generally set at corporate headquarters in a meeting held weekly. At this meeting the manager in charge of setting prices for a given product will look at a variety of information including: (a) any manufacturer wholesale price changes and promotions, (b) past sales for this product, and (c) competitors' prices from the last week. Based on these information and discussions with other managers, the corporate manager in charge of price setting will decide whether to change prices, and if so, by how much. We do not have data on these costs although it is likely that the wage rates of pricing managers at the corporate headquarters are higher than at the store level. Also, since the pricing decisions made at the corporate level have chain-wide significance, it is likely to include more considerations than price change issues arising at the store level. We should note, however, that these pricing decision are made for the entire chain and therefore, these costs per store may not be as high, especially for the larger chains. ${ }^{20}$

\section{PRICE CHANGE ACTIVITY OF THE CHAIN DRUGSTORE}

We find that the chain drugstore changes prices on an average of 1,131 products each week. Of these price changes, 694 are promotional price changes. Specifically, 401 are sale price changes, 250 are budget buy changes, 14 are rebates, and 10 are clearance items (see Table 4). It is clear from these figures that a great deal of the price change activity in the chain drugstore is promotional in nature. Over $61 \%$ of the price changes seem to have some advertising or merchandising dimension. In the grocery industry promotional pricing of some form is also the norm in many categories. ${ }^{21}$ This points to the promotional nature of price changes in many retail establishments where posted prices are the norm.

This suggests that the benefits to frequently changing prices through promotions can be high when firms post prices. For example, Hoch et. al. (1995) find that high/low pricing was more profitable than a flatter every-day-low-price strategy for the stores in their sample. ${ }^{22}$ Carlton (1986) has suggested that changing prices frequently can make it more difficult for customers to compare prices of branded items across retail outlets due to higher search costs. This would be similar to 
using price complexity to create differentiation between retail outlets. Similarly, Bergen et. al. (1996) show how product variation can be used to create complexity, induce higher search costs, and thereby lead to differentiation across retail outlets. ${ }^{23}$ Also note that the promotional price changes observed in the usual retail settings (such as supermarkets, drugstores, department stores, hardware stores, etc) usually involve price fluctuation between the regular and few sale prices. For example, prices are often marked down by, say 10 or 20 percent, typically for a period of one week or sometimes two, and at the end of the "sale" period prices go back to the original level. ${ }^{24}$ This suggests that such traditional forms of temporary sales may be designed to assure the consumers that a markdown this week is not likely to be followed by an even larger markdown next week (Okun, 1981; Warner and Barsky, 1995; and Warner, 1995).

It is also interesting to note that promotional prices are set during different days of the week in the different retail formats. In the chain drugstore this is done on Fridays, tied to weekend advertisements, whereas at supermarket stores it is typically done early in the week. Thus drugstores' advertising and price change process is more in line with weekend shopping considerations (Warner and Barsky, 1995). This is probably due to the differences in the buying process of drugstore and supermarket customers. Traditionally food sections in local newspapers are published midweek, such as on Wednesdays, and supermarkets often choose to promote their products in those sections. Comparing the shopping behavior of supermarket customers with drugstore customers, supermarket weekly shopping is more regular than drugstore trips. This is probably because of the large number of items we have to buy on a weekly basis. Further, most food items are not durable and hence they have to be purchased more frequently. Most of us have experienced writing or using a shopping list. And food expenditures are significant enough to be part of family budgets. Therefore, given the weekly shopping planning cycle, supermarket customers may need a day or two to be able to use the promotional information effectively. ${ }^{25}$

\section{TIMING OF PRICE CHANGES}

We also have some evidence that these firms' pricing scheme has some time-dependent element. The price changes of the chain drugstore are done regularly on a weekly basis, which is very similar to the weekly pricing cycle reported by Dutta, et al. (1998) and Levy, et al. (1997, 1998) for large US supermarket chains. The prices at the stores of this particular chain drugstore are changed on the same days of the week (see Table 4). Specifically, the stores change the majority of their prices on Mondays. These include all unadvertised prices of cosmetics and over-the-counter drugs, which make up 65 percent of the labor cost (730 weekly price changes of the total 1,131). The remaining 35 percent of the labor cost is spent on changing prices of all advertised products (401 weekly price 
changes), which is done on Fridays. Thus all price changes are done within a period of two days. Levy et. al. (1997) provide evidence (reproduced in the right hand side of Table 4) that the large U.S. supermarket chains tend to follow a similar practice. ${ }^{26}$ Specifically, they find that 96.4 percent of the weekly price changes in the supermarket chains are done during a two day (Sunday and Monday) period, on a regular basis. Lach and Tsiddon (1996b) suggest that at a multiproduct firm, storespecific menu costs may induce this kind of price change timing synchronization. Many components of menu costs we document in this paper are indeed store-specific, rather than product-specific.

This similarity in the price change process provides empirical evidence in support of the idea that firms selling many products and relying on posted prices, tend to use a form of time-dependent pricing rules, as predicted by Carlton (1989) and Sheshinski and Weiss (1977). This may be due to the large amount of information and coordination effort required to change the prices of huge number of products they carry. This is consistent also with arguments made by Danziger (1983), Caballero (1989), and Ball and Mankiw (1994), who suggest that time-dependent price adjustments of the type documented here can be optimal if the cost of gathering information about the state exceeds the cost of making the price adjustment itself. It could also be due to the use of promotional pricing, which requires advance planning with the newspapers (or other advertising outlets) and may be tied to the consumer buying patterns, weekly shopping phenomenon in the case of supermarkets, or sporadic weekend shopping at drugstores. Overall, our evidence identifies two major retail formats that use a version of time-dependent pricing rules providing some empirical support to the common use of such rules in the cost of adjustment literature. ${ }^{27}$

\section{CONCLUSIONS}

In this paper we present an analysis of the price change process at a large US drugstore chain, and report the results of direct measurements of some components of menu costs this chain faces. We find that menu costs per price change for the drugstore chain are similar in magnitude to those reported for large US supermarket chains by Levy et al. (1997). We also show that both retail formats rely heavily on promotional pricing strategies, and that both use a form of time-dependent

pricing rules. This suggests that at least some components of menu costs we study, are likely to be generalizable across much wider variety of multiproduct retail formats that use posted prices.

While our data do not talk directly to the issue of monetary non-neutrality, recall that menu costs are relevant even if they are small since they may be sufficient to generate large aggregate rigidity. Therefore, as Blinder (1994), Kashyap (1995), and Slade (1998) emphasize, it is important to search for direct evidence that such costs are indeed present at the micro level. By directly identifying, documenting, and measuring the magnitude of menu costs at the store level we are taking an important step in that direction. Clearly much work remains to be done. 
A possible ironic limitation of this study is that if the electronic shelf label systems were some day in the future widely adopted, many of these physical components of the menu costs could be greatly diminished. Unfortunately for the electronic shelf label company, as of today, the retail industry has been slow to adopt this technology, however. This seems to be due to the difficulty of measuring all the benefits of the electronic shelf label system, the high direct cost of the system (about $\$ 150,000$ ), strict capital investment constraints, limited applicability of the technology in some departments (for example, the electronic shelf label system does not work well with peg, cosmetics, and pharmacy labels), and a concern over the evolving technology standard and technological obsolescence.

It should be emphasized, however, that even if these technologies are widely adopted, there are significant components of menu costs which the electronic shelf label systems were not designed to save, and therefore these menu cost components are here to stay. They include the costs of managerial decisions such as the information gathering costs and "thinking costs," and the costs born by consumers directly and indirectly due to the price changes. For example, Ritson at al. (1998) report preliminary measures of these managerial and consumer menu costs for an industrial firm and find that these menu costs seem to exist in the entire organization. Moreover, they find that these costs may be significantly larger than the physical costs of changing prices. These preliminary findings reinforce the importance of studying the magnitude and the structure of the managerial and customer menu costs, which are unlikely to change in the foreseeable future despite the potential changes in the physical price change technology.

This study can be extended also to other retail formats and markets. Although we would expect our results to generalize to some of the retail settings with posted prices, it is not clear how our results will generalize to many other industry settings. This is because there are a variety of industries for which the steps involved in changing prices would be significantly different from those reported here. For example, business-to-business sales which often rely on a salesforce, will require changes in the list price sheets, changes in the instructions to the salesforce, etc. The business-tobusiness prices also often have more complex pricing schemes including quantity discounts, bundling, and individually negotiated prices. Similarly, the very composition of menu costs is likely to vary from market to market, such as magazines at newsstands (Cecchetti, 1986) or products sold through catalogues (Kashyap, 1995). Therefore, future empirical work should look at these menu costs in a variety of other industries, markets and countries, and should also consider other types of menu costs. ${ }^{28}$ 


\section{LITERATURE CITED}

Akerlof, George A., and Janet L. Yellen. "A Near-Rational Model of Business Cycle, with Wage and Price Inertia." Quarterly Journal of Economics 100 (1985), 823-838.

Amano, Robert A., and R. Tiff Macklem. "Menu Costs, Relative Prices, and Inflation: Evidence for Canada." Working Paper, Research Department, Bank of Canada (1995).

Andersen, Torben M. Price Rigidity: Causes and Macroeconomic Implications. Oxford: Clarendon Press, 1994.

Balke, Nathan S. and Mark A. Wynne. "Supply Shocks and the Distribution of Price Changes." Federal Reserve Bank of Dallas Economic Review, (1996), 10-18.

Ball, Laurence, and N. Gregory Mankiw. "A Sticky-Price Manifesto." Carnegie-Rochester Conference Series on Public Policy (1994), 127-152.

— . "Relative Price Changes as Aggregate Supply Shocks." Quarterly Journal of Economics (1995), 161-93.

Ball, Laurence, N. Gregory Mankiw, and David Romer. "The New Keynesian Economics and the Output-Inflation Trade-off.” Brookings Papers on Economic Activity 1 (1988), 1-65.

Bergen, Mark, Shantanu Dutta, and Steven M. Shugan. "Using Branded Variants." Journal of Marketing Research 33 (1996), 9-19.

Blanchard Olivier J., and Nobuhiro Kiyotaki. "Monopolistic Competition and the Effects of Aggregate Demand." American Economic Review 77 (1987), 647-666.

Blattberg, Robert C. and Scott A. Neslin. Sales Promotion: Concepts, Methods, and Strategies. Englewood Cliffs, NJ: Prentice Hall, 1989.

Blinder, Alan S. "Why Are Prices Sticky? Preliminary Results from an Interview Study." American Economic Review 81 (1991), 89-96.

_ . "On Sticky Prices: Academic Theories Meet the Real World." in Monetary Policy, edited by N. Gregory Mankiw, pp. 117-150. NBER: University of Chicago Press, 1994.

Blinder, Alan S., Elie R.D. Canetti, David E. Lebow, and Jeremy B. Rudd. Asking About Prices: A New Approach to Understanding Price Stickiness. New York, NY: Russell Sage Foundation, 1998.

Buckle, Robert A. and John A. Carlson. "Inflation and Asymmetric Price Adjustment." Working Paper No. 96-013, Center for International Business Education and Research, Purdue 
University.

Caplin, Andrew. "Individual Inertia and Aggregate Dynamics," in Optimal Pricing, Inflation, and the Cost of Price Adjustment, edited by E. Sheshinski and Y. Weiss, pp. 19-45. Cambridge, MA: The MIT Press, 1993.

Caplin, Andrew S., and John Leahy. "State Dependent Pricing and the Dynamics of Money and Output." Quarterly Journal of Economics 106 (1991), 683-708.

— . "Aggregation and Optimization with State-Dependent Pricing." Econometrica 65 (1997), $601-625$.

Caplin, Andrew S., and Daniel F. Spulber. "Menu Costs and the Neutrality of Money." Quarterly Journal of Economics 102 (1987), 703-725.

Carlson, John A. "Some Evidence on Lump Sum Versus Convex Costs of Changing Prices." Economic Inquiry 30 (1992), 322-331.

Carlton, Dennis W. “The Rigidity of Prices.” American Economic Review 76 (1986), 637-58.

. "The Theory and the Facts of How Markets Clear: Is Industrial Organization Valuable for Understanding Macroeconomics?" in Handbook of Industrial Organization, Volume 1, edited by Richard Schmalensee and Robert D. Willig, pp. 909-946. Amsterdam: North Holland, 1989.

Carlton, Dennis W., and Jeffrey M. Perloff. Modern Industrial Organization. New York, NY: Harper Collins, 1994.

Cecchetti, Stephen G. "The Frequency of Price Adjustment: A Study of the Newsstand Prices of Magazines." Journal of Econometrics 31 (1986), 255-274.

Danziger, Leif. "Price Adjustments with Stochastic Inflation.” International Economic Review 24 (1983), 699-707.

- "Inflation, Fixed Cost of Price Adjustments, and Measurement of Relative Price Variability." American Economic Review 77 (1987), 704-713.

— . "A Dynamic Economy with Costly Price Adjustment." American Economic Review, forthcoming, 1999.

Dutta, Shantanu, Mark Bergen, and Daniel Levy. "Price Flexibility in Channels of Distribution: Evidence From Scanner Data.” Working Paper, Emory University, 1998.

Eden, Benjamin. "Time Rigidities in the Adjustment of Prices to Monetary Shocks: An Analysis of 
Micro Data.” Discussion Paper No. 94.16, Bank of Israel, 1994.

- "The Choice of Nominal Price Changes by Individual Stores: An Empirical Analysis of Data From High Inflation Periods." Working Paper No. 96/01, The University of Haifa, 1995.

— . "Inflation and Price Dispersion: An Analysis of Micro Data." W.P. 96/02, University of Haifa, 1996.

Gordon, Robert J. “What is New-Keynesian Economics?” Journal of Economic Literature 28 (1990), 1115-1171.

Hoch, Stephen J., Xavier Drèze, and Mary E. Purk. "EDLP, Hi-Lo, and Margin Arithmetic." Journal of Marketing 58 (1994), 16-27.

Kashyap, Anil K. "Sticky Prices: New Evidence from Retail Catalogues.” Quarterly Journal of Economics 110 (1995), 245-274.

Lach, Saul, and Daniel Tsiddon. "The Behavior of Prices and Inflation: An Empirical Analysis of Disaggregated Data.” Journal of Political Economy 100 (1992), 349-389.

- "Staggering and Synchronization in Price-Setting: Evidence from Multiproduct Firms." American Economic Review 86 (1996a), 1175-1196.

—_ "Small Price Changes and Menu Costs.” WP No. 96.06, The MFIER, Jerusalem, 1996 b.

Levy, Daniel, Mark Bergen, Shantanu Dutta, and Robert Venable. "The Magnitude of Menu Costs: Direct Evidence from Large U.S. Supermarket Chains.” Quarterly Journal of Economics 112 (August 1997), 791-825.

Levy, Daniel, Shantanu Dutta, Mark Bergen, and Robert Venable. "Price Adjustment at Multiproduct Retailers.” Managerial and Decision Economics 19 (February 1998), 81-120.

Levy, Daniel, Shantanu Dutta, and Mark Bergen. "Heterogeneity in Price Rigidity and Shock Persistence.” working paper, University of Chicago and Emory University, 1996.

Liebermann, Yehoshua, and Ben-Zion Zilberfarb. "Price Adjustment Strategy Under Conditions of High Inflation: An Empirical Examination.” Journal of Economics and Business 37 (1985), 253-265.

Mankiw, N. Gregory. "Small Menu Costs and Large Business Cycles: A Macroeconomic Model of Monopoly." Quarterly Journal of Economics 100 (1985), 529-539.

Mankiw, N. Gregory and David Romer. New Keynesian Economics. Cambridge, MA: MIT 
Press, 1991.

Meltzer, Allan H. "Information, Sticky Prices, and Macroeconomic Foundations." Federal Reserve Bank of St. Louis Review 77 (1995), 101-118.

Nagle, Thomas T. and Reed K. Holden. The Strategy and Tactics of Pricing. Second Edition, Englewood Cliffs, NJ: Prentice Hall, 1995.

Okun, Arthur M. Prices and Quantities: A Macroeconomic Analysis. Washington, DC: The Brookings Institution, 1981.

Parkin, Michael. “The Output-Inflation Trade-off When Prices Are Costly to Change.” Journal of Political Economy. 94 (1986), 200-224.

Quelch, John A. "Vaseline Petroleum Jelly." Case Study, Chesebrough-Pond's Inc., Harvard Business School, 1981.

Ritson, Mark, Mark Zbarcky, Daniel Levy, Mark Bergen, and Shantanu Dutta. "Managerial Menu Costs in Industrial Markets." Manuscript to be presented at the 1999 American Economic Association Meeting in New York (1998).

Romer, David. Advanced Macroeconomics. New York, NY: McGraw-Hill, 1996.

Rotemberg, J.J. "Sticky Prices in the United States.” Journal of Political Economy 90 (1982), 1187-1211.

Sheshinski, Eytan, Asher Tishler, and Yoram Weiss. "Inflation, Costs of Price Adjustments, and the Amplitude of Real Price Changes: An Empirical Analysis," in Development in an Inflationary World, edited by J. Flanders and Assaf Razin. New York, NY: Academic Press, 1981.

Sheshinski, Eytan, and Yoram Weiss. "Inflation and Costs of Price Adjustments." Review of Economic Studies 44 (1977), 287-303.

- Optimal Pricing, Inflation, and the Cost of Price Adjustment. Cambridge, MA: The MIT Press, 1993.

Slade, Margaret E. "Sticky Prices in a Dynamic Oligopoly: An Investigation of (s, S) Thresholds," The University of British Columbia, manuscript, 1996.

— "Optimal Pricing with Costly Adjustment: Evidence from Retail-Grocery Prices." Review of Economic Studies 65 (1998), 87-107. 
Warner, Elizabeth J. "Pricing in the Retail Industry: A Case Study." Hamilton College, 1995.

Warner, Elizabeth J. and Robert Barsky. "The Timing and Magnitude of Retail Store Markdowns: Evidence from Weekends and Holidays." Quarterly Journal of Economics 110 (1995), $321-52$.

Wynne, Mark A. "Sticky Prices: What is the Evidence?" Federal Reserve Bank of Dallas Economic Review (First Quarter, 1995), 1-12. 


\section{FOOTNOTES}

1. By promotional price changes we mean not only advertised price changes such as regular sales, rebates, and clearance sales, but also in-store feature advertisings such as "Manager's Special," “Today’s Special,” This Week’s Advertised Feature," “Compare and Save,” end-of-the-aisle displays, etc.

2. Here we briefly describe the dataset. For more details, see Levy et al. (1997).

3. The company that provided us with the data, is also the source of the data used by Levy, et al. (1997).

4. The specific chain we study operates two types of stores. One type of store is the standard standalone store. The second type of store is located inside a supermarket chain. The representative sample stores selected for the study that collected the data set we use here included both types of stores, at least two of each type. The figures reported here are their averages. These stores are identical to each other in terms of pricing practice, price change frequency, store size, and managerial structure. The only main difference between them is in the type of products carried. For example, the stores located within supermarkets are carrying more items not sold by the supermarket. Overall, the stand-alone stores tend to carry greater variety of products in comparison to the stores located within supermarkets. In our sample, the difference in the number of products carried was about 15 percent.

5. The source of these figures is "Positive Sign: Chain Drugstore Sales Came on Strong in 1995, National Association of Chain Drug Stores Reports," Drug Topics, January 8, 1996, Vol. 140, No. 1, p. 91 .

6. The total revenue estimate of $\$ 81.4$ billion is an average of two estimates we were able to find: (i) \$80.8 billion reported in “Annual Drugstore Sales Nearly Double in Decade,” Drug Topics, June 13, 1994, Vol. 138, No. 11, p. 118; and (ii) $\$ 82.4$ billion estimate derived by Nielsen company from its Household Panel Survey as reported in "Latest Nielsen Data: Inside Today’s Drugstore 
Shopper," Drug Topics, June 13, 1994, Vol. 138, No. 11, 89-100.

7. The source of this figure is a national trade publication which explicitly identifies the drugstore chain we study, and therefore, to protect the chain's anonymity, we cannot report the exact reference. It should be mentioned, however, that an internal study of the electronic shelf label company reports a similar figure. Although chain drug stores often have about 20,000-25,000 universal product code (UPC) numbers in their computer database, there are usually no more than about 15,000 products actually carried at any given time. The extra universal product code numbers are for seasonal sizes and packages of products, for promotional packages and products, and for discontinued products.

8. Note, however, that this does not mean that after about one year prices of all products the store carries have been changed. This is because many product prices are changed very infrequently. Unfortunately, our data contains no information on the distribution of price changes across specific product categories.

9. The adjustment factor, 0.7948 , is the ratio of total weekly price changes $(1,131)$ and total weekly price tag changes $(1,423)$. The measures of the various menu cost components reported by the electronic shelf label company are based on the weekly price tag changes which in addition to price changes also includes replacement for damaged or lost price tags. Since the cost of a price tag change should count as part of the menu cost only to the extent that it involves actual price change, we have adjusted all menu cost measures we report here downwards by the factor 0.795 to capture only the cost of the price tag changes that are related to actual price changes.

10.While our measures of labor cost could overstate the true cost of changing price if the drugstore chain hoards labor to save hiring and firing costs, this is not likely to be the case for several reasons. First, the estimated cost of the labor used in changing price is based on actual time and motion measurements of the minimum amount of time and labor required to accomplish the task. Second, the adjustment in the amount of labor is usually done through hours worked, which makes cost of hiring and firing less relevant. And third, the workers on the floor are routinely 
moved from task to task (which include stocking, cleaning, inventory checking, price changing, price checking, customer service, cash register, etc.) and so the opportunity cost of changing a price is not zero.

11.According to Levy, et al. (1997, Table II), about 85 percent of the resources devoted to changing price tags and price signs in the retail supermarket chains, are used in the stages of price tag change process, price tag change verification, handmade price sign change process, and preprinted price sign change process. Further, Levy, et al. (1998, Figures 3, 4, 8, and 9 and their corresponding Tables 4, 6, 10, and 11) report that most time consuming steps undertaken during these stages must be repeated each time a price is changed.

12.Consistent with these arguments are these facts: (1) Most of the products in the drugstore have a longer shelf-life than in the supermarket, (2) inventory turnover is much slower in the drugstore, and (3) drugstores are not volume driven to the same extent as supermarkets.

13.We also report menu cost figures relative the number of products carried as well as relative to store's gross revenues (see the first two rows of Table 3). These calculations yield menu cost per product carried of $\$ 1.31$, and menu cost to gross margin ratio of 1.71 percent.

14. This is consistent with the findings of Blinder, et al. (1998) who report that 69.1 percent of the pricing managers they surveyed face nontrivial costs of changing prices which they consider important barrier to frequent price changes. Furthermore, 43 percent of the firms indicate the presence of explicit costs of price adjustment, and additional 21 percent — the presence of explicit, but trivial, costs of price adjustment. Thus, their findings suggest that over 69 percent of the price managers in their sample seem to face a fixed cost of changing price, that is menu cost. Only 13.6 percent percent of the managers interviewed indicated a presence of some version/s of a convex cost of adjustment. (The remaining 17.3 percent indicated a presence of both, fixed as well as convex costs of adjustment.) In sum, the overwhelming majority of the firms surveyed seem to face some form of menu cost. 
15. Menu cost per price change, $\$ 0.33$, we report here is lower than the figures reported by Slade (1998). There are several possible reasons for this: (1) our menu cost figures are based on actual measurements of the resources that go into the price change process, whereas she estimates menu costs econometrically as model coefficients using a mix of store-level price and aggregate cost data; (2) we cover 15,000 products the chain drugstore carries rather than a single product category; (3) our menu cost figures do not include all components of menu costs; and (4) there could be differences in wage rates which may be important given the significance of the labor cost component in menu costs.

16.See Note (b) underneath Table 2 for details. It is likely that the chain drugstores also incur these forms of menu costs. Indeed, discussions with chain drugstore managers reveal that handling mistakes, especially for promoted and advertised items, can lead to lost cashier and management time, refunds, lost customer goodwill, and inventory mistakes associated with incorrect shelf tags_-just as in supermarket chains. See Levy, et al. (1997, 1998).

17.These figures are calculated using the Citibase series RTRR (IV-3-1), RTZ541 (IV-3-2), and RTZ591 (IV-3-2).

18.The ratio of the Citibase series GAGR (X-6-15) to GADP (X-6-14) is 9.3 percent.

19.See, for example, Ball and Mankiw (1994), Kashyap (1995), and Meltzer (1995). Since the electronic shelf label system was not designed to save the costs of corporate headquarter managerial time spent on price change decisions, the electronic shelf label company did not measure this component of menu costs.

20.Levy et al. (1997) estimate that the chainwide managerial decision costs for supermarket chains fall in the range of $\$ 2.3-\$ 2.9$ million a year, or about $\$ 7,250$ per store. They show, however, that a decentralization of the price change decisions may easily double (or even triple) the store-level menu costs.

21.For example, Dutta, Bergen, and Levy (1998) and Levy, Dutta, and Bergen (1996) find that at one 
major midwestern supermarket chain in the frozen and refrigerated orange juice categories, at least one of the three brands of the orange juice they studied, was promoted every week throughout the year. Thus at least $1 / 3$ of the category was being promoted, and an even higher percentage of the category was being sold at promoted prices.

22.Under the every-day-low-price strategy, the retailer's prices are low for an extended periods of time and therefore it will offer fewer promotional sales or discounts. Under the high/low pricing strategy, in contrast, the retailer's prices are higher, and the retailer tends to offer more frequent discounts through sales and promotions. The pricing strategy, therefore, will have an effect on the frequency of price changes observed.

23.Another reason for the frequent price changes of the drugstore chain is the fierce competition it faces (Blattberg and Neslin, 1989; Nagle and Holden, 1995). The margin in the retail drugstore industry is $2-3$ percent at most. The main reason for such a low margin is the extent of competition with many national and regional chains all competing in each market. Also, there is a strong competition in many product categories such as health, beauty, paper products, and analgesics, from non-drugstore retailers, including grocery stores, supermarket chains, discount stores, and mass merchandisers. Note that product categories such as health, beauty, paper products, and analgesics, are the categories which experience the majority of the price changes, and this seems to be directly related to the level of competition in the retail drugstore industry.

24.Similar sale patterns have been documented for the retail orange juice market by Dutta, Bergen, and Levy (1998) and Levy, Dutta, and Bergen (1996).

25.This is especially true if they use coupons which must be clipped from the newspaper.

26.Note that the existence of such a work-week schedule may make search costs and demand elasticities vary across the week.

27.This does not mean, however, that state dependent pricing rules are unimportant. Even if price 
changes across product categories follow a prescheduled weekly time table, the decision on prices of which products to change is likely to contain a state-dependent component. For example, it could depend on changes in supply and demand conditions such as competitors price change decisions. Lach and Tsiddon (1996b) suggest that a multiproduct retailer experiencing both, storespecific and product-specific shocks, are likely to make both, time-dependent as well as statedependent types of price adjustments. It should be mentioned that, unfortunately, the data we have do not allow us to be more specific about the nature of time vs state dependence of the price changes at this drugstore chain. In particular, based on the data have, we cannot really tell whether the probability of changing a price is a function of the number of periods that have elapsed since that last change occurred, or perhaps that probability is history-independent.

28.As another interesting extension one could use the data reported in this paper and in Levy, et al. (1997) to calibrate a new Keynesian model of business cycle to see whether the magnitude of the menu costs we find is adequate for a sticky price model to produce predictions that match the data. 
Table 1. Weekly Frequency of Price Changes

\begin{tabular}{|l|c|c|}
\hline & $\begin{array}{c}\text { Drugstore } \\
\text { Chain }\end{array}$ & $\begin{array}{c}\text { Supermarket } \\
\text { Chains }^{\mathrm{a}}\end{array}$ \\
\hline Approximate number of products carried & 15,000 & 25,000 \\
\hline $\begin{array}{l}\text { Number of price changes per } \\
\text { store per week }\end{array}$ & 1,131 & 3,916 \\
\hline $\begin{array}{l}\text { Percentage of products for which prices } \\
\text { change in an average week }\end{array}$ & $7.54 \%$ & $15.66 \%$ \\
\hline
\end{tabular}

(a) The data for supermarket chains are reproduced from Levy, et al. (1997), Table I, average of Chains A-D. See the text for details. 
Table 2. Absolute Measures of the Annual Menu Costs Per Store (1992 dollars)

\begin{tabular}{|c|c|c|}
\hline Menu cost component & $\begin{array}{l}\text { Drugstore } \\
\text { Chain }\end{array}$ & $\begin{array}{l}\text { Supermarket } \\
\text { Chains }^{\mathrm{a}}\end{array}$ \\
\hline $\begin{array}{l}\text { Labor cost of price changes (includes costs of price change preparation and price } \\
\text { change verification) }\end{array}$ & $\$ 15,461$ & $\$ 74,267$ \\
\hline Costs of printing and delivering new price tags & $\$ 4,159$ & $\$ 6,014$ \\
\hline Total annual menu costs of labor and new price tags per store & $\$ 19,620$ & $\$ 80,281$ \\
\hline Costs of mistakes made during the price change process & $\$ 4,193^{b}$ & $\$ 20,140$ \\
\hline Costs of in-store supervision of the price change process & $\$ 1,138^{b}$ & $\$ 5,466$ \\
\hline Total annual menu cost per store & $\$ 24,951$ & $\$ 105,887$ \\
\hline
\end{tabular}

(a) The data for supermarket chains are reproduced from Levy, et al. (1997), Table III, average of Chains A-D, the sum of labor cost of price and sign changes (rows 1 and 2). The shares of price change preparation, price changes, and price change verification in the total labor cost of price and sign changes for the supermarket chains are reported in Levy, et al. (1998). See the text for more details.

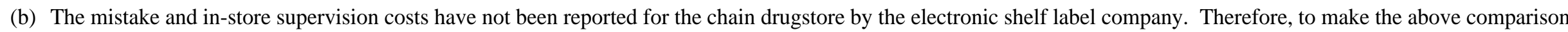
possible, we have estimated them using the ratio of these two components relative to the total labor cost of price changes, as reported for the supermarket chains in the right hand side column of the above table. Thus, by assumption, the ratio of the mistake cost/labor costs is the same across the two retail formats, 0.2712 in this case. Similarly, the ratio of the in-store supervision cost/labor cost is the same across the two retail formats, 0.0736 in this case. 
Table 3. Relative Measures of Menu Cost (1992 dollars) ${ }^{\mathrm{a}}$

\begin{tabular}{|l|c|c|}
\hline & Drugstore Chain & Supermarket Chains \\
\hline Menu cost of labor and new price tags per product carried ${ }^{\mathrm{b}}$ & $\$ 1.31$ & $\$ 3.21$ \\
\hline Menu cost of labor and new price tags/gross marginc & $1.71 \%$ & $2.13 \%$ \\
\hline Menu cost of labor and new price tags/net margins ${ }^{\mathrm{d}}$ & $21.30 \%$ & $0.67 \%$ \\
\hline Menu cost of labor and new price tags/revenues & $0.59 \%$ & $\$ 0.39$ \\
\hline Menu cost of labor and new price tags per price changef & $\$ 0.33$ & $35.17 \%$ \\
\hline \hline Total menu cost/net margins & $27.08 \%$ & $0.70 \%$ \\
\hline Total menu cost/revenues & $0.74 \%$ & $\$ 0.52$ \\
\hline Total menu cost per price change & $\$ 0.42$ & 26.5 \\
\hline
\end{tabular}

(a) All five relative measures of menu costs reported in the top five rows of the table, use the total annual menu costs of labor and new price tags (Table 2, row 3) as the numerator. The bottom three measures (lower panel) use the total annual menu cost (Table 2, bottom row) as the numerator.

(b) The number of products carried comes from the first row of Table 1.

(c) The annual gross margin per store for the supermarket chains is $\$ 3,763,179$ per store on average, based on 25 percent of revenues reported in note (3) below (Hoch, Drèze, and Purk, 1994; and Supermarket Business, "Consumer Expenditures Study,” Vol. 48, 1993, p. 52). For the drugstore chain, it equals $\$ 1,148,000$ per store on average, based on 28 percent of revenues (given in note e below) as reported by Corporate Growth Report ("Corporate Growth Strategies in a Recession, July 1991, Vol. 9, No. 7, p. 4) for a similar chain drugstore, Walgreen Co.

(d) The average annual net margin for the supermarket chains is $\$ 301,054$ per store, based on 2 percent of revenues. (Montgomery, 1994). For the chain drugstore it equals \$92,125 based on 2.75 percent of revenues (Almanac of Business and Industrial Financial Ratios, Englewood Cliffs, NJ: Prentice Hall, 1996). The revenue figures are provided in note (e) below.

(e) Average annual revenue per store for the supermarket and drugstore chains are $\$ 15,052,716$ and $\$ 3,350,000$, respectively. The source of the former figure is Supermarket Business ("Consumer Expenditures Study," Vol. 48, 1993, p. 52). The latter figure is an average of two estimates we were able to find: $\$ 4,100,000$ revenue reported for the leading drugstore chain, Walgreen Co, by Barron's (“A Winning Prescription,” March 7, 1994, Vol. 74, No. 10, p. 21), and $\$ 2,600,000$ revenue reported (in a private conversation) by a manager of a smaller chain drugstore.

(f) The number of price changes comes from the second row of Table 1. 
Table 4. Weekly Schedule of Price Changes and their Frequency by Type of Merchandise

\begin{tabular}{|c|c|c|c|c|c|}
\hline \multicolumn{3}{|c|}{ Chain Drugstore } & \multicolumn{3}{|c|}{ Supermarket: Chain $\mathrm{A}^{\mathrm{a}}$} \\
\hline Type of merchandise & $\begin{array}{l}\text { Number of products for } \\
\text { which prices change }\end{array}$ & $\begin{array}{l}\text { Time of the week when } \\
\text { the prices are changed }\end{array}$ & Type of merchandise & $\begin{array}{c}\text { Number of products for } \\
\text { which prices change }\end{array}$ & $\begin{array}{l}\text { Time of the week when } \\
\text { the prices are changed }\end{array}$ \\
\hline $\begin{array}{l}\text { All advertised } \\
\text { products (sales) }\end{array}$ & $\begin{array}{r}401 \\
(35.4 \%)\end{array}$ & Friday & & & \\
\hline $\begin{array}{l}\text { Basic price related } \\
\text { changes }\end{array}$ & $\begin{array}{r}437 \\
(38.6 \%)\end{array}$ & Monday & $\begin{array}{l}\text { General merchandise, } \\
\text { advertised }\end{array}$ & $\begin{array}{r}72 \\
(1.7 \%)\end{array}$ & Saturday \\
\hline Budget buy & $\begin{array}{r}250 \\
(22.1 \%)\end{array}$ & Monday & Grocery & $\begin{array}{r}2,100 \\
(49.1 \%)\end{array}$ & Sunday \\
\hline Compare and save & $\begin{array}{r}19 \\
(1.7 \%)\end{array}$ & Monday & Market (produce) & $\begin{array}{r}171 \\
(4.0 \%)\end{array}$ & Sunday \\
\hline Clearance items & $\begin{array}{r}10 \\
(0.9 \%)\end{array}$ & Monday & $\begin{array}{l}\text { General } \\
\text { merchandise }\end{array}$ & $\begin{array}{r}1,853 \\
(43.3 \%)\end{array}$ & Monday \\
\hline Rebate & $\begin{array}{r}14 \\
(1.2 \%)\end{array}$ & Monday & Grocery, advertised & $\begin{array}{r}82 \\
(1.9 \%)\end{array}$ & Tuesday \\
\hline $\begin{array}{l}\text { Total number of } \\
\text { weekly } \\
\text { price changes }\end{array}$ & $\begin{array}{r}1,131 \\
(100 \%)\end{array}$ & & $\begin{array}{l}\text { Total number of } \\
\text { weekly } \\
\text { price changes }\end{array}$ & $\begin{array}{r}4,278 \\
(100 \%)\end{array}$ & \\
\hline
\end{tabular}

(a) The data for the supermarket are reproduced from Levy, et al. (1997), Table VI. 